\title{
OPTIMALISASI PERILAKU PEMASANGAN INFUS MELALUI PELATIHAN PEMASANGAN INFUS PADA MAHASISWA
}

\author{
Iswati \\ Akademi Keperawatan Adi Husada Surabaya \\ iswatisaja@yahoo.com
}

\begin{abstract}
ABSTRAK
Memasang infus merupakan salah satu tindakan invasif yang harus dapat dilakukan oleh mahasiswa perawat, namun demikian tidak semua mahasiswa keperawatan memiliki kemampuan dan kompetensi untuk melakukan tindakan tersebut.Tujuan penelitian ini untuk mengetahui adanya pengaruh pelatihan pemasangan infus terhadap pengetahuan, sikap dan tindakan dalam memasang infus. Desain penelitian yang digunakan pre experimental design dengan bentuk pre-post test design without control group , analisis data menggunakan uji beda T-Test untuk melihat adanya perbedaan sebelum dan sesudah dilakukan intervensi. Populasi dalam penelitian mahasiswa semester 4, sampel diambil yang memenuhi kriteria inklusi. Teknik sampling yang digunakan purposive sampling.Pengumpulan data menggunakan kuesioner dan lembar observasi Hasil dari penelitian ini menunjukkan bahwa terdapat pengaruh pelatihan yang dilakukan terhadap perilaku mahasiswa dalam melakukan pemasangan infus.Mahasiswa disarankan untuk terus belajar dan dapat memanfaatkan kesempatan saat praktik dirumah sakit atau klinik agar kemampuan memasang infus dapat lebih terlatih.Dosen pembimbing harus memisahkan mahasiswa yang memiliki kemampuan kurang dan memberikan bimbingan tambahan.
\end{abstract}

Kata kunci: pelatihan, pemasangan infus, perilaku.

\begin{abstract}
Giving infusion is one invasive procedure that should be performed by nursesstudents, however, not all nursing students have the ability and competence to perform those actions. The purpose of this research is to find out the influence from training infusion to knowledge, attitude and practice in an Action to give infusion. The design study is pre experimental design with a form of pre-post test design without control group, analysis of data using different test T-Test to see the differences before and after intervention. The population in the 4th semester student research, the sample was taken that met the inclusion criteria. The sampling technique used purposive sampling. Collecting data using questionnaires and observation sheet. The results of this study indicate that there are significant training performed on the behavior of the students in doing infusion.Students are advised to continue to learn and can take advantage of the opportunity when the practice in a hospital or clinic so the ability to give infusion can be trained. The lecturer must separate the students who have less ability and provide additional guidance.
\end{abstract}

Keywords: training, infusion, behavior.

\section{PENDAHULUAN}

Pemberian cairan intravena merupakan tindakan memberikan cairan intravena melalui akses vena yang telah dibuat dengan tujuan untuk memberi serta mempertahankan terapi cairan intravena. ${ }^{7}$ Pemberian terapi intravena (iv) atau yang sering disebut dengan pemasangan infus, merupakan tindakan yang umum dilakukan oleh perawat, bahkan calon perawat yang masih berstatus mahasiswa juga harus memiliki pengalaman memasang infus. Namun, tidak semua mahasiswa dapat memasang infus, bahkan ada yang hingga lulus, belum memiliki pengalaman dalam melakukan tindakan ini.
Berdasarkan survei yang telah dilakukan pada16 Maret 2016, peneliti telah memilih 10 orang untuk dikaji mengenai pengalamannya dalam memasang infus.1 dari 10 orang menyatakan pernah mencoba melakukan tindakan pemasangan infus namun belum berhasil.2 orang menyatakan belum pernah melakukan tindakan dalam pemasangan infus. Dua orang selanjutnya menyatakan belum mendapat kesempatan memasang infus karena kondisi dan keinginan pasien untuk langsung dipasang oleh perawat senior, dan 3 orang terakhir menyatakan belum pernah memasang infus karena takut bila gagal.

Ketepatan dalam memasang infus dipengaruhi oleh beberapa faktor, antara lain 
pemilihan lokasi pemasangan, apabila pemilihan lokasi pemasangan tidak tepat maka pemasangan infus akan gagal; factor lain adalah persiapan dari diri perawat, perawat dalam melakukan tindakan invasif harus benar - benar menguasai materi serta prosedur teknik terkait pemasangan infus; factor lainnya adalah keadaan psikologis pasien, yang lebih memilih perawat senior untuk memasang infus karena ragu dengan kemampuan mahasiswa yang belum memiliki pengalaman; faktor lain adalah kondisi pasien yang tidak memungkinkan serta adanya pengalaman gagal saat dipasang infus sebelumnya.

Apabila mahasiswa belum pernah mendapatkan kesempatan dan pengalaman memasang infus, maka hal ini juga akan menyulitkan mahasiswa dalam mencari pekerjaan, karena sebagai seorang calon perawat pengalaman memasang infus salah satu hal yang sering ditanyakan saat wawancara melamar pekerjaan.Selain itu, belum adanya pengalaman yang cukup dapat menyebabkan ketrampilan mahasiswa tidak berkembang dan seringkali cemas bila ditempatkan di tempat praktik yang baru, karena harus menyiapkan diri untuk beradaptasi dengan lingkungan yang baru serta alat kesehatan yang mungkin berbeda dari sebelumnya. Upaya yang dapat dilakukan untuk meningkatkan pengetahuan, sikap serta tindakan mahasiswa dalam memasang infus, maka perlu diadakan pelatihan yang digunakan untuk mengevaluasi kemampuan mahasiswa dari segi pengetahuan, sikap, serta tindakan baik sebelum (pre) maupun sesudah (post) diadakan pelatihan. Berdasarkan uraian latar belakang diatas, peneliti tertarik untuk melakukan penelitian tentang pengaruh pelatihan memasang infus terhadap pemasangan infus pada mahasiswa Akper Adi Husada Surabaya Semester 4.

Berdasarkan paparan diatas, maka dapat dirumuskan pertanyaan penelitian sebagai berikut: Adakah pengaruh pelatihan pemasangan infus terhadap perilaku mahasiswa dalam pemasangan infus pada mahasiswa semester 4 di Akper Adi Husada Surabaya. Tujuan Penelitian ini untuk mengidentifikasi perilaku pemasangan infus pada mahasiswa semester 4 Akper Adi Husada Surabaya.

\section{METODE}

Penelitian ini menggunakan metode pre experimental design dengan bentuk pre-post test design without control group. ${ }^{6}$ Penelitian ini dilaksanakan pada April 2016 di Akademi Keperawatan Adi Husada Surabaya.
Populasinya semua mahasiswa Semester 4 Akademi Keperawatan Adi Husada Surabaya yang berjumlah 84 orang, sampel yang diambil adalah sebagian dari populasi, dengan kriteria sampel: bersedia untuk diteliti, nilai praktik KMB "C", jumlah sampel sebanyak 27 orang. Teknik sampling yang digunakan purposive sampling. Variabel independen dalam penelitian adalah pelatihan pemasangan infus. Variabel dependen dalam penelitian ini adalah perilaku pemasangan infus. Pelatihan pemasangan infuse dilaksanakan sebanyak empat kali pertemuan. Pada pertemuan 1 sebelumnya diambil data pre dan pada akhir pertemuan 4 diambil data post. Alat pengumpul data yang digunakan adalah kuesioner dan lembar observasi. Analisa data yang digunakan adalah T-test.

\section{HASIL}

\section{Karakteristik Responden}

Berdasarkan jenis kelamin sebagian besar (81\%) responden berjenis kelamin perempuan, berusia 20 - 22 tahun (85\%), beragama Islam $(96 \%)$

\section{Pengalaman Dalam Melakukan Pemasangan Infus \\ Tabel 1.Pengalaman Mahasiswa memasang Infus

\begin{tabular}{|c|c|c|c|}
\hline No. & Variabel & $\mathbf{n}$ & $\%$ \\
\hline & Pengalaman & & \\
\hline & Memasang Infus & & \\
\hline & Pernah & 7 & 26 \\
\hline & Belum Pernah & 20 & 74 \\
\hline & Jumlah & 27 & 100 \\
\hline
\end{tabular}

Tabel 1 menunjukkan bahwa sebagian besar responden belum pernah melakukan pemasangan infus.

\section{Frekuensi Pemasangan Infus Saat Praktik Di Ruangan}

Tabel 2. Frekuensi Pemasangan Infus Saat Praktik Di Ruangan.

\begin{tabular}{|c|c|c|c|}
\hline No. & Variabel & $\mathbf{n}$ & $\%$ \\
\hline & & 5 & 16 \\
\hline & & 2 & 8 \\
\hline & kali & 0 & 0 \\
\hline & $\mathrm{m}$ pernah & 20 & 74 \\
\hline & Jumlah & 27 & 100 \\
\hline
\end{tabular}

Tabel 2 menunjukkan bahwa sebagian besar responden belum pernah melakukan pemasangan infus yaitu 20 responden $(74 \%)$. 
Pengetahuan (Knowledge) Mahasiswa Tentang Pemasangan Infus

Tabel 3 Pengetahuan Mahasiswa tentang Pemasangan Infus.

\begin{tabular}{lccc}
\hline No. Variabel & Mean & Median & $\begin{array}{c}\text { Min }- \\
\text { Max }\end{array}$ \\
\hline $\begin{array}{l}\text { 1. Pengetahuan } \\
\text { Sebelum }\end{array}$ & 17,44 & \multirow{2}{*}{18,00} & $13,00-$ \\
& & & 20,00 \\
Sesudah & 18,96 & \multirow{2}{*}{19,00} & $16,00-$ \\
& & & 20,00 \\
\hline
\end{tabular}

Tabel 3 menunjukkan bahwa terjadi peningkatan pengetahuan sebelum dan sesudah dilakukan pelatihan pemasangan infus.

Sikap (Attitude) $\quad$ Mahasiswa
Pemasangan Infus

Tabel 4 Sikap Mahasiswa Dalam Pemasangan Infus.

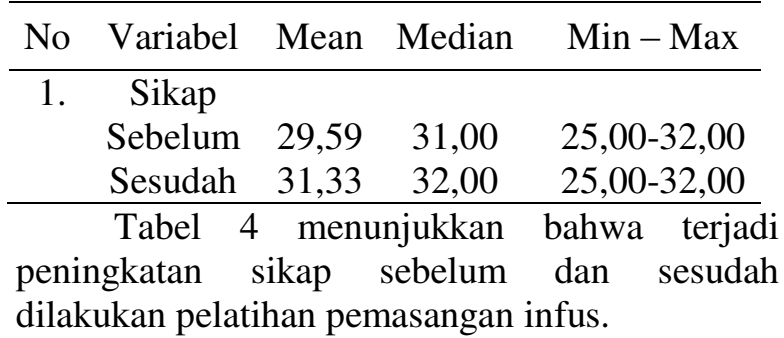

Tindakan (Practice) Mahasiswa Dalam Pemasangan Infus

Tabel 5 Tindakan Mahasiswa Dalam Pemasangan Infus.

\begin{tabular}{ccccc}
\hline No & Variabel & Mean & Median & Min - Max \\
\hline 1. & Tindakan & & & \\
& Sebelum & 17,78 & 18,00 & $15,00-20,00$ \\
& Sesudah & 18,89 & 19,00 & $17,00-20,00$ \\
\hline \multicolumn{4}{c}{ Tabel 5 menunjukkan terjadi ketrampilan, } \\
sebelum dilakukan pelatihan dan sesudah \\
dilakukan pelatihan.
\end{tabular}

\section{Pengaruh Pelatihan}

Tabel 6 Perbedaan Tingkat Pengetahuan, Sikap Dan Tindakan Sebelum Dan Sesudah Pelatihan Pemasangan Infus

\begin{tabular}{lccccc}
\hline \multicolumn{1}{c}{ Pelatihan } & Mean & SD & SE & P Value & N \\
\hline Pengetahuan & & & & & \\
\hline Pre Pelatihan & 17,50 & 1,726 &, 339 &, 000 & 26 \\
Post Pelatihan & 18,96 &, 999 &, 196 & & 26 \\
\hline Sikap & & & & & \\
\hline Pre Pelatihan & 29,59 & 2,664 &, 513 &, 010 & 27 \\
Post Pelatihan & 31,33 & 1,664 &, 320 & & 27 \\
\hline Tindakan & & & & & \\
\hline Pre Pelatihan & 17,78 & 1,423 &, 274 &, 002 & 27 \\
Post Pelatihan & 18,89 &, 892 &, 172 & & 27 \\
\hline
\end{tabular}

$* \mathrm{p}=<0,05$

Tabel 6 menunjukkan terdapat perbedaan pada pengetahuan, sikap serta tindakan dalam pemasangan infus sebelum dan sesudah pelatihan.

PEMBAHASAN

\section{Pengetahuan (Knowledge) Tentang Pemasangan Infus}

Berdasarkan hasil penelitian yang telah dilakukan, sebagian besar responden rata - rata berusia 20-22 tahun. Hasil penelitian ini menunjukkan bahwa tidak ada hubungan antara tingkat pengetahuan seseorang dengan usia. Hal ini disebabkan karakteristik usia pada responden memiliki distribusi yang normal dan homogen, sehingga tidak terlihat adanya perbedaan serta hubungan terhadap tingkat pengetahuan tentang pemasangan infus. Sama halnya dengan agama dan jenis kelamin, tidak memiliki pengaruh terhadap tingkat pengetahuan seseorang, karena sebagian besar agama dan jenis kelamin pada responden berdistribusi normal dan homogen sehingga tidak memiliki pengaruh terhadap tingkat pengetahuan responden.

Berdasarkan hasil uji statistik yang telah dilakukan menggunakan uji T-Test, didapatkan hasil nilai $\mathrm{p}<0,05$ yaitu sebesar $\mathrm{p}=0,000$, yang menunjukkan bahwa terdapat pengaruh dari pelatihan yang diadakan terhadap pengetahuan tentang pemasangan infus. Pelatihan yang dilakukan meliputi pemberian materi dengan metode presentasi, dilengkapi dengan pemutaran video tentang pemasangan infus, diskusi disertai dengan pembagian materi pelatihan di akhir pelatihan untuk masing - masing responden. Menurut Kamus Besar Bahasa Indonesia (2011), pengetahuan adalah sesuatu yang diketahui berkaitan dengan proses pembelajaran. Proses belajar ini dipengaruhi berbagai faktor dari 
dalam, seperti motivasi dan faktor luar berupa sarana informasi yang tersedia, serta keadaan sosial budaya. Pendapat lain juga diungkapkan oleh Agus (2013), yang menyatakan bahwa pengetahuan adalah informasi atau maklumat yang diketahui atau disadari oleh seseorang. Menurut Notoadmodjo (2012), pengetahuan dapat di dipengaruhi oleh beberapa hal, salah satunya adalah umur seseorang. Pendidikan adalah sebuah proses mengubah sikap dan tata laku seseorang atau kelompok dan juga usaha mendewasakan manusia melalui upaya penguraian atau pelatihan.

Pernyataan ini sesuai dengan hasil penelitian yang telah dilakukan oleh Supriyanto (2008) tentang hubungan antara tingkat pendidikan perawat dengan kepatuhan penerapan prosedur tetap pemasangan infus di ruang rawat inap RSDM Surakarta. Dalam penelitiannya, Supriyanto (2008) mengungkapkan tidak ada hubungan yang signifikan antara usia perawat dengan kepatuhan penerapan protap pemasangan infus di ruang rawat inap RSDM Surakarta. Mahasiswa semester 4 yang menjadi responden penelitian, memiliki latar belakang yang sama, yaitu memiliki pengalaman pembelajaran yang sama serta telah mendapatkan praktika laboratorium pemasangan infus. Selain itu, responden juga telah melakukan praktik di rumah sakit Adi Husada Kapasari dan Adi Husada Undaan Wetan. Namun pada pelatihan dan uji statistik yang dilakukan menunjukkan bahwa nilai $p$ sebesar 0,000 yang menunjukkan pelatihan ini telah memberikan pengaruh terhadap pengetahuan mahasiswa tentang pemasangan infus dan juga terjadi peningkatan yang signifikan dari 17,50 menjadi 18,96. Hal ini sesuai dengan teori yang diungkapkan oleh Prabu (2009), bahwa salah satu tujuan dari pelatihan adalah mengembangkan keterampilan perawat baik dari segi pengetahuan.Sehingga pelatihan yang dilakukan telah berhasil meningkatkan pengetahuan mahasiswa semester 4 tentang pemasangan infus.

\section{Sikap (Attitude) Tentang Pemasangan Infus}

Berdasarkan hasil penelitian yang telah dilakukan, didapatkan sebagian besar responden memiliki sikap yang positif dan terjadi peningkatan setelah dilakukan pelatihan pemasangan infus sebesar 25,00 (78\%) menjadi $32,00(100 \%)$ dari skor total $32(100 \%)$. Hal ini menunjukkan bahwa sikap responden positif terhadap stimulus yang diberikan yaitu berupa pelatihan pemasangan infus. Menurut Wahid Iqbal Mubarak, dkk (2007) sikap merupakan suatu reaksi atau respons seseorang terhadap stimulus atau objek. Sikap dalam kehidupan sehari - hari merupakan reaksi yang bersifat emosional terhadap suatu stimulus.Sikap merupakan kesiapan seseorang dalam bertindak. Menurut Notoatmodjo (2010), sikap merupakan reaksi atau respon seseorang yang masih tertutup terhadap suatu stimulus atau objek. Sikap belum merupakan suatu tindakan atau aktivitas, akan tetapi merupakan factor predisposisi tindakan suatu perilaku. Sikap itu masih merupakan reaksi tertutup, bukan merupakan rekasi terbuka.Heri Purwanto (1998) mengungkapkan dalam A. Wawan \& Dewi M (2010), sikap dapat pula bersifat positif maupun negative. Sikap positif cenderung menunjukkan sikap yang mendekati, menyenangi, merespons dan mengharapkan objek tertentu. Sikap negatif terdapat kecenderungan untuk menjauhi, menghindai, membenci, tidak merespons dan tidak menyukai objek tertentu.

Selain terjadi peningkatan, berdasarkan uji statistic yang telah dilakukan menunjukkan nilai $p$-value $=0,010$ yang berarti terdapat pengaruh pelatihan terhadap sikap mahasiswa dalam melakukan pemasangan infus. Hal ini dapat diamati pula oleh peneliti sebelum, selama dan setelah pelatihan berlangsung, Peserta memberikan respon yang positif yaitu tetap antusias mengikuti pelatihan karena sebagian besar responden mengungkapkan bahwa pemasangan infus merupakan tindakan yang sangat penting, sehingga adanya pelatihan ini dapat membantu responden untuk mempersiapkan diri pada praktika klinik selanjutnya, karena sebagai seorang calon perawat, pemasangan infus merupakan tindakan yang penting dan harus dikuasi dengan baik sejak dini.

\section{Tindakan (Practice) Tentang Pemasangan Infus}

Berdasarkan hasil penelitian yang telah dilakukan, terdapat peningkatan ketrampilan responden sebelum dilakukan pelatihan dan sesudah dilakukan pelatihan, yaitu 14,00 (70\%) menjadi $20,00(100 \%)$ dari skor total $20(100 \%)$. Hal ini menunjukkan bahwa ada peningkatan ketrampilan responden dalam melakukan pemasangan infus.Menurut Dunnete (2006) keterampilan (practice) adalah kapasitas yang dibutuhkan untuk melaksanakan beberapa tugas yag merupakan pengembangan dari hasil training dan pengalaman yang didapat. Hal ini sependapat dengan Nadler (2007) yang mengungkapkan ketrampilan (skill) adalah kegiatan yang memerlukan praktik atau dapat diartikan sebagai implikasi dari aktivitas.Selain itu tindakan atau ketrampilan (practice) merupakan kemampuan 
seseorang dalam melakukan sesuatu atau suatu kegiatan (KBBI, 2011).

Selain terjadi peningkatan, berdasarkan uji statistic yang telah dilakukan menunjukkan nilai p sebesar 0,002 yang berarti terdapat pengaruh pelatihan terhadap tindakan mahasiswa dalam melakukan pemasangan infus. Untuk meningkatkan ketrampilan seseorang, maka perlu diadakannya pembelajaran yang terus menerus dan kemampuan tersebut harus terus dilatih sampai pada akhirnya menjadi trampil atau mahir terhadap suatu hal. Selain harus dilatih, seseorang harus memiliki sikap serta kesiapan untuk mau belajar agar kemampuannya dapat meningkat. Hal yang dapat mempengaruhi ketrampilan seseorang adalah adalah pengalaman pribadi, pengaruh antar teman, lingkungan social serta tersedianya fasilitas pendukung. Meskipun responden memiliki pengalaman yang sama dalam mendapat pembelajaran tentang materi pemasangan infuse, baik pada mata kuliah Kebutuhan Dasar Manusia (KDM) maupun Keperawatan Medikal Bedah (KMB), namun sebelum dan setelah dilakukan pelatihan terdapat peningkatan ketrampilan responden dalam melakukan tindakan pemasangan infus. Sehingga dapat dikatakan pelatihan yang telah dilakukan oleh peneliti berhasil.

\section{Pengaruh Pelatihan Terhadap Perilaku Mahasiswa dalam Melakukan Pemasangan Infus}

Pada tabel 6 menunjukkan bahwa hasil pengetahuan sebelum dan sesudah mendapatkan pelatihan memiliki pengaruh dengan nilai $\mathrm{p} \leq$ 0,05 , yaitu didapatkan nilai $\mathrm{p}=0,002$, yang menunjukkan bahwa terdapat pengaruh pelatihan terhadap pengetahuan mahasiswa dalam pemasangan infus. Untuk sikap didapatkan $\mathrm{p}$ sebesar 0,010 yang menunjukkan bahwa pelatihan yang dilakukan memiliki pengaruh terhadap sikap mahasiswa dalam pemasangan infus. Untuk tindakan didapatkan nilai 0,002 yang menunjukkan bahwa terdapat pengaruh pelatihan terhadap praktik atau tindakan pemasangan infus pada mahasiswa semester 4 Akper Adi Husada Surabaya. Sehingga dapat diketahui bahwa terdapat peningkatan yang signifikan pada pengetahuan, sikap dan tindakan atau praktik pada mahasiswa semester 4 Akper Adi Husada Surabaya dalam pemasangan infus.

Menurut Marquis \& Houston (2012) pelatihan merupakan metode terorganisasi yang memastikan bahwa seseorang mempunyai pengetahuan dan keterampilan untuk tujuan khusus dan bahwa mereka mendapatkan pengetahuan yang dibutuhkan untuk melakukan tugas kerja, lebih lanjut dikatakan bahwa pelatihan memiliki manfaat segera, seorang manajer harus mampu mengenali dan mendorong aktivitas pendidikan karena hal ini merupakan peran dan tanggung jawab pemimpin. Menurut Sri Wiludjeng (2007) terdapat beberapa faktor yang dapat mempengaruhi berhasilnya suatu pelatihan, antara lain: Penentuan kebutuhan pelatihan dan pengembangan, pemilihan metode serta pemilihan media untuk melaksanakan pelatihan. Selain itu berhasilnya suatu pelatihan yang telah dilakukan adalah terdapat adanya perbedaan pada sebelum dan sesudah pelatihan.

Pelatihan yang telah dilakukan oleh peneliti, menggunakan pemilihan metode pelatihan coaching dan laboratory training dimana dalam metode ini, pelatih memberikan arahan dalam pemberian teori dan praktik kepada responden serta menggunakan peralatan yang telah disiapkan sebelumnya. Untuk metode presentasi informasi, peneliti menggunakan metode presentasi video tentangpelaksanakan tindakan pemasangan infus.Setelah diberikan pelatihan terdapat peningkatan yang signifikan sebelum dan sesudah pelatihan.

\section{SIMPULAN DAN SARAN}

Ada perbedaan pengetahuan, sikap dan tindakan mahasiswa dalam melakakan pemasangan infus, sebelum dan sesudah pelatihan memasang infus. Mahasiswa disarankan untuk terus belajar dan dapat memanfaatkan kesempatan saat praktik dirumah sakit atau klinik agar kemampuan memasang infus dapat lebih terlatih. Dosen pembimbing harus memisahkan mahasiswa yang memiliki kemampuan kurang dan memberikan bimbingan tambahan.

\section{DAFTAR PUSTAKA}

1. A. Anwar Prabu Mangkunegara. 2006. Evaluasi Kinerja Sumber Daya Manusia. Jakarta: Refika Aditama.

2. A.A. Anwar Prabu Mangkunegara. 2009. Manajemen Sumber Daya Manusia. Bandung : PT. Remaja Rosdakarya.

3. Agus Suprijono. 2013. Cooperative Learning Teori dan Aplikasi PAIKEM. Yogyakarta : Pusaka Pelajar.

4. Departemen Pendidikan Nasional. 2011. Kamus Besar Bahasa Indonesia Pusat Bahasa. Jakarta: PT. Gramedia Pustaka Utama.

5. Hamalik, Oemar. 2007. Pengembangan SDM Manajemen Pelatihan Ketenagakerjaan Pendekatan Terpadu. Jakarta : Bumi Aksara. 
6. Hastono, Sutanto . 2007. Analisa Data Kesehatan. Jakarta : Universitas Indonesia.

7. Kusyati, Eni. 2012. Keterampilan Dasar Prosedur Keperawatan. Jakarta : EGC.

8. Marquis dan Huston (2010). Kepemimpinan dan manajemen keperawatan. Teori dan Aplikasi. Alih bahasa: Widyawati dan Handayani. Jakarta. Edisi 4. EGC.

9. Notoatmodjo, Soekidjo. 2010. Metodologi Penelitian Kesehatan. Jakarta :Rineka Cipta.

10. Prabu Mangkunegara. 2006. Evaluasi Kinerja SDM. Jakarta: Bumi Aksara

11. Sugiyono, 2007. Statistika Untuk Penelitian. Alfabeta. Cetakan Kesebelas: Bandung.

12. Triton, PB. 2009. Mengelola Sumber Daya Manusia. Yogyakarta : Oryza.

13. Wawan, A dan Dewi, M. 2010. Teori Pengukuran Pengetahuan, dan Perilaku Manusia. Yogyakarta : Nuha Medika. 